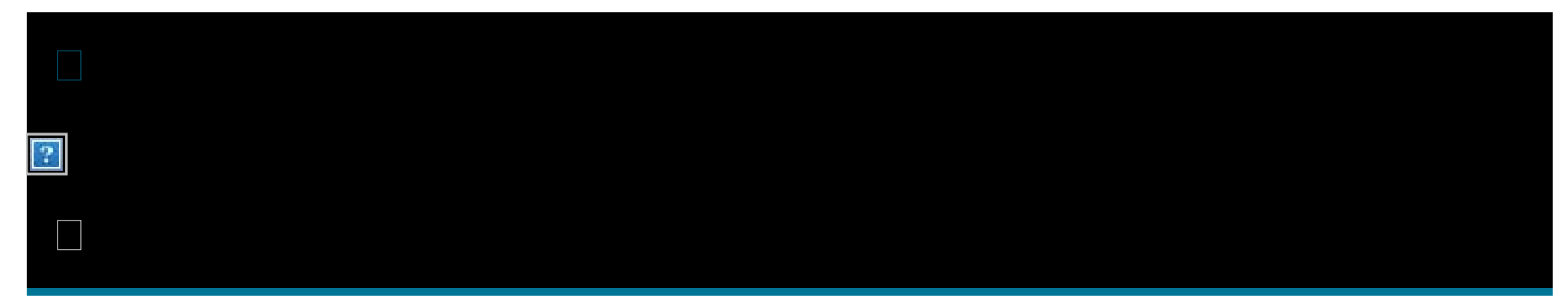

Source Title: Clinical Chemistry and Laboratory Medicine (CCLM) | Volume/Issue: Volume 58: Issue 1

\title{
Pre-analytical and analytical confounders of serum calprotectin as a biomarker in rheumatoid arthritis
}

Lieve Van Hoovels email, Bert Vander Cruyssen, Laura Bogaert, Stefanie Van den Bremt and Xavier Bossuyt

DOI: https://doi.org/10.1515/cclm-2019-0508 | Published online: 30 Oct 2019

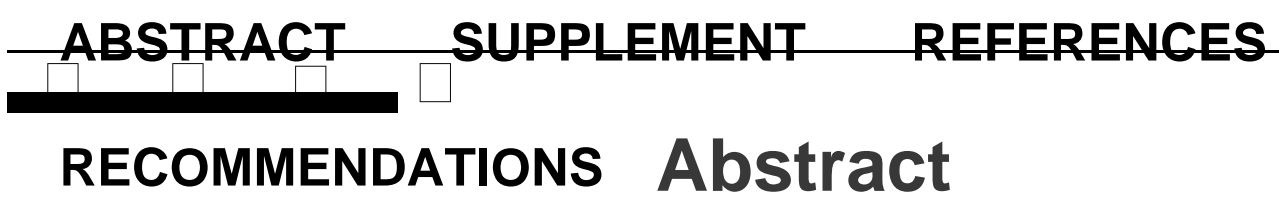

\section{Background}

There is a need for additional biomarkers to assist in the diagnosis and prognosis of rheumatoid arthritis (RA). The aim of our study was to evaluate the (pre-analytical, analytical and clinical) performance of serum calprotectin as a marker of inflammation in RA.

\section{Methods}

The study population included 463 rheumatologic patients (including 111 RA patients and 352 
controls) who for the first time consulted a rheumatologist, 20 healthy controls and 27 patients with an infectious disease. Calprotectin was measured (using four different assays) in serum or in serum and EDTA plasma (healthy controls and infectious disease group). For rheumatologic patients, results for C-reactive protein (CRP), erythrocyte sedimentation rate (ESR), rheumatoid factor (RF) and anticyclic citrullinated peptide antibody (ACPA) were available.

\section{Results}

Results for blood calprotectin were assay- and matrix-dependent, with higher values found in serum than in plasma. Serum calprotectin was higher in RA patients than in rheumatologic diseased controls and in healthy controls. Serum calprotectin was lower in RA patients than in patients with an infectious disease. Serum calprotectin was associated with disease activity (DAS score). The area under the curve (AUC) to discriminate RA from controls was 0.756 for CRP, 0.714 for ESR and $0.726-0.783$ for calprotectin.

\section{Conclusions}

Our data document that calprotectin measurement is assay- and matrix-dependent. Serum calprotectin is associated with disease activity. Additional (prospective) studies are warranted to further evaluate the prognostic and diagnostic value of blood calprotectin measurements.

Keywords: biomarker; rheumatoid arthritis; serum calprotectin

\section{PURCHASE ARTICLE}

Get instant unlimited access to the article.

or

REDEEM TOKEN

or 


\section{LOG IN}

Already have access? Please log in.

\section{Enter your username}

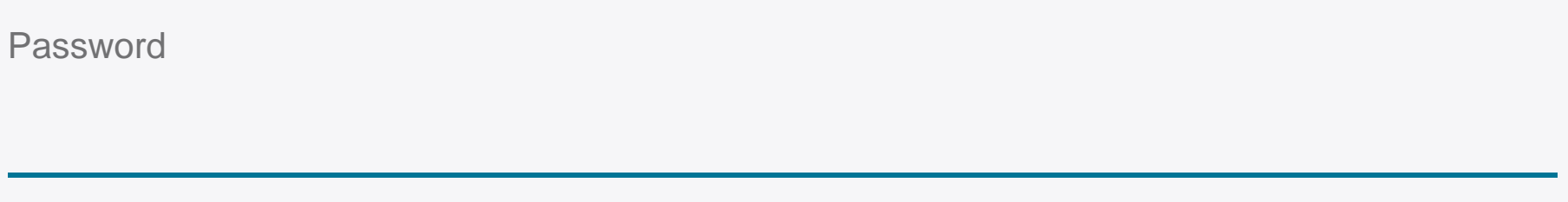

FORGOT YOUR PASSWORD?

\section{$\log \operatorname{In}$}

or

LOG IN WITH YOUR INSTITUTION

\section{Article information}

Received: 2019-05-20

Accepted: 2019-09-15

Published Online: 2019-10-30

Published in Print: 2019-12-18

Citation Information: Clinical Chemistry and Laboratory Medicine (CCLM), Volume 58, Issue 1, Pages 40-49, eISSN 1437-4331, ISSN 1434-6621, DOI: https://doi.org/10.1515/cclm-2019-0508.

(C)2020 Walter de Gruyter GmbH, Berlin/Boston.

Get Permission

JOURNAL + ISSUES 


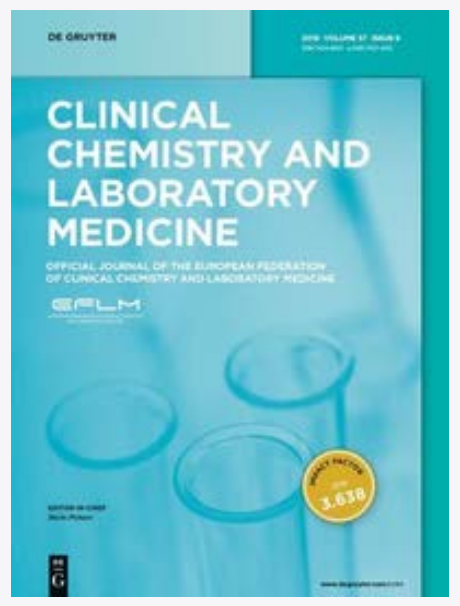

\section{Clinical Chemistry and Laboratory Medicine (CCLM)}

\section{Volume 58: Issue 1}

Clinical Chemistry and Laboratory Medicine ( CCLM) publishes articles on novel teaching and training methods applicable to laboratory medicine. CCLM welcomes contributions on the progress in fundamental and applied research and cutting-edge clinical laboratory medicine. It is one of the leading journals in the field, with an impact factor of over three. CCLM is the official journal of nine national clinical societies and associated with EFLM.

Online ISSN: 1437-4331

First published: 01 Jan 1963

Language: English

Edited by: Philippe Gillery, Ronda Greaves, Karl J. Lackner, Giuseppe Lippi, Bohuslav Melichar, Deborah A. Payne and Peter Schlattmann

Publisher: De Gruyter

\section{SEARCH}

Search within Journal... 


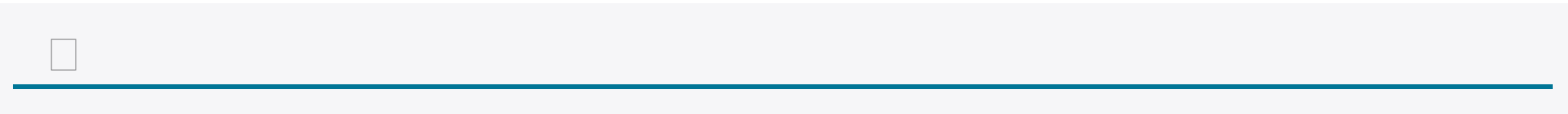

O Issue O Journal

\title{
Volume
}

Issue

\section{Page}

Authenticated by

\section{KU LeUVEN Libraries}

\section{IMPRINTS}

\author{
BIRKHÄUSER \\ DE GRUYTER MOUTON \\ DE GRUYTER OLDENBOURG \\ DE GRUYTER SAUR \\ DEUTSCHER KUNSTVERLAG \\ EDITION KLAUS SCHWARZ \\ JOVIS
}

CONTACT \& SERVICE

\section{HELP CENTER}

CONTACT

CAREER

OUR LOCATIONS

IMPRINT

\section{STAY IN TOUCH}




\section{BLOGS}

\section{NEWSLETTER}

\section{PRIVACY POLICY TERMS AND CONDITIONS DISCLAIMER}

\section{(C) Walter de Gruyter GmbH 2020}

Powered by PubFactory

What do you want to do ?

New mail copy

: 